\title{
ANALISIS PENERAPAN GOOD UNIVERSITY GOVERNANCE PADA PERGURUAN TINGGI DI KOTA JAYAPURA
}

\author{
Rudiawie Larasati $^{1)}$, Meinarni Asnawi ${ }^{2)}$, Yundy Hafizrianda ${ }^{3)}$ \\ Program Magister Akuntansi, Universitas Cenderawasih \\ 1) E-mail: ademaularasati@yahoo.co.id
}

\begin{abstract}
Abstrak
Penelitian ini bertujuan untuk mengetahui model Good University Governance pada perguruan tinggi kota Jayapura dengan menggunakan Informan anggota SPI dalam penentukan bobot prioritas menggunakan model Analytical Hierarchy Process. Serta untuk mengetahui penerapan Good University Governance di Kota Jayapura. Prinsip Good University Governance dalam penelitian ini menggunakan lima aspek yaitu Transparansi, Akuntabilitas, Responsibilitas, Independensi dan Keadilan.

Penelitian ini menggunakan sampel perguruan tinggi yang berjumlah empat perguruan tinggi, yaitu UNCEN, UNIYAP, STIIE PORT NUMBAY dan USTJ. Dengan jumlah responden sebanyak 76 responden.

Hasil penelitian ini menunjukkan bahwa model GUG yang dihasilkan oleh penentuan bobot anggota SPI memiliki nilai tertinggi pada variabel independensi yaitu dengan nilai sebesar 0,227, kemudian Transparansi sebesar 0,209, urutan ketiga ada pada akuntabilitas sebesar 0,206, urutan keempat ada pada Keadilan sebesar 0,201 dan urutan terakhir pada variabel responsibilitas sebesar 0,157 .

Penerapan GUG pada perguruan tinggi kota Jayapura masuk kedalam kriteria "Tinggi” dengan total skor 79,19 yaitu masuk pada interval 60,00-80,00. Oleh sebab itu disimpulkan bahwa penerapan GUG pada perguruan tinggi di kota Jayapura sudah dilaksanakan dengan baik.
\end{abstract}

Kata kunci: Transparansi, Akuntabilitas, Responsibilitas, Independensi, Keadilan dan Analitical Hierarcy Process (AHP). 


\section{Pendahuluan}

Konsep pendidikan tinggi didunia awalnya diperkenalkan di Amerika Serikat sekitar tahun 1970-an. Ini adalah sebuah pengakuan terhadap hak-hak rakyat Amerika untuk memperoleh pendidikan tinggi. Dalam konteks Indonesia, hal yang sama juga berlaku bahwa segenap warga negara Indonesia memiliki hak yang sama dalam mengakses sumber-sumber pendidikan tinggi yang ada.

Kesejahteraan bangsa terletak pada kualitas pendidikannya, yang berdasarkan pada kualitas sumber daya manusia khususnya penguasaan ilmu pengetahuan dan teknologi untuk meningkatkan kesejahteraan masyarakat. Dengan adanya pengetahuan yang bermanfaat akan menekan angka kemiskinan, dan meningkatkan kualitas lingkungan hidup serta keunggulan kompetetif maupun komparatif suatu bangsa.

Perguruan tinggi menanggung beban sejarah dalam pembangunan bangsanya melalui relasi timbal balik dengan pemerintah, sektor swasta, dan masyarakat sipil. Tanpa pendidikan tinggi yang berumutu, prestisius dan berkelas dunia, daya saing bangsa tidak akan meningkat secara signifikan. Dengan demikian, universitas sebagai manufaktur pengetahuan (manufacture of knowlage) harus senantiasa memeriksa posisi sentralnya di tengah masyarakat berbasis pengetahuan (knowledge based society).(Wijatno, 2009)

Selain itu pentingnya komunitas kaum intelektual pada perguruan tinggi merupakan, sebagai perubahan (agent of change) dalam mengatasi permasalahan-permasalahan di masyarakat. Terdapat tiga kewajiban yang harus diterapkan di perguruan tinggi yakni pendidikan, penelitian dan pengabdian masyarakat yang disebut dengan Tri Darma Perguruan Tinggi merupakan media dalam mewujudkan perubahan sosial. Transfer atau konservasi ilmu menjadi peran utama dan menjadi tolak ukur di institusi perguruan tinggi sekaligus diharapkan menjadi kelompok intelektual yang memegang teguh nilai-nilai luhur guna menjunjung tinggi suatu bangsa. (Eli, 2013). Kelompok intelektual harus menjadi filter untuk menyesuaikan diri dari lingkungan di luarnya yang mengandung unsur keburukan serta menyimpang dari aturan yang ada.

Dalam konteks Indonesia, yang sebagaimana di negara-negara berkembang lainnya, pendidikan tinggi dihadapkan pada tiga tantangan penting, yaitu: 1 . Peningkatan kualitas, relevansi, ekuiti, efisiensi, dan governance 2. Posisi pendidikan tinggi sebagai kekuatan moral untuk membantu dalam mengarahkan demokratisasi di masyarakat dan reformasi sosial politik 3. Adanya tantangan baru yang muncul akibat konstruksi ekonomi pengetahuan, internasionalisasi, dan kompetisi antar negara yang semakin meningkat (Esha, 2011).

Tidak hanya di sektor privat saja yang menerapkan Corporate Governance, sektor pendidikan pun mulai mengarahkan sistem teta kelola yang yang baik dan ideal yang disebut dengan konsep Good University Governance.

Konsep GUG muncul akibat dari berbagai masalah pengelolaan perguruan yang tinggi. Dari masalah administrasi hingga korupsi. Pada penelitian yang dilakukan oleh Indonesia Corruption Watch menemukan kasus tindak pidana korupsi yang terjadi di beberapa perguruan tinggi negeri di Indonesia. Kasus korupsi tersebut telah berjumlah 37 kasus selama 10 tahun terakhir. Hal ini disebabkan kurang transparannya dalam pengelolaan keuangan menjadi peluang berbagai pihak tertentu untuk melakukan fraud Sehingga anggaran yang diberikan kepada PTN tidak dapat ditelusuri jumlahnya serta pengalokasinya anggaran tersebut.

Kasus Korupsi di Perguruan Tinggi ternyata telah melibatkan civitas akademik yaitu pegawai atau pejabat structural di fakultas maupun univesitas yang berjumlah 32 orang. Menurut penelitian ICW juga menjelaskan bahwa rektor atau wakil rektor bahkan termasuk mantan rektor adalah pelaku terbanyak kedua dengan jumlah 13 pelaku. Sebagai lembaga yang menangani pemberantasan korupsi, KPK juga tidak cukup memberikan informasi terkait adanya korupsi di dunia pendidikan. Karena alangkah lebih baik jika lembaga antirasuah itu juga melakukan penindakan selama data dan bukti yang diperlukan sudah cukup. 
Pengelolaan universitas secara langsung dipengaruhi oleh kebijakan pemerintah dengan menitikberatkan pada aspek efisiensi. Selain itu juga pentinganya efektifitas manajemen dan tata kelola universitas memunculkan tiga prinsip utama yaitu, otonomi kelembagaan yang harus dihormati, kebebasan akademik harus dilindungi serta pengaturan tata kelola harus terbuka dan responsive. (Trakman \& South, 2008)

Menurut UGSC (University Governance Screening Card) 2012 tata kelola universitas membahas bagaimana sebuah universitas dapat memaksimalkan sistem pendidikanya demi pencapain tujuan organisasi, melakukan pengelolaan program akademik, meningkatan pengetahuan mahasiswa, mengelola asset dan keuangan hingga peningkatan keahlihan sumber daya manusia di lingkup universitas. UGSC menggunakan lima dimensi: (1) Konteks, Misi, \& Tujuan Secara Keseluruhan; (2) Orientasi Manajemen; (3) Otonomi; (4) Akuntabilitas; (5) Partisipasi.

Namun berbeda dengan model Good University Governance menurut Trakman \& South (2008) yang membagi model GUG menjadi lima yaitu : (1) faculty;

(2) Corporate; (3) trustee governance; (4) stakeholder; (5) amalgam models of governance.

Sedangkan regulasi tentang pengelolaan universitas di Indonesia tercantum dalam UU No. 12 Tahun 2012 Tentang Pendidikan Tinggi, Pasal 63 mengharuskan pengelolaan perguruan tinggi yaitu berdasarkan 5 prinsip yaitu, transparansi, akuntabilitas, penjamin mutu, efektifitas dan efisiensi, serta nirlaba.

Menurut Wijatno, 2009 pengelolaan perguruan tinggi terbagi 5 prinisp yaitu (1) Transparansi, Akuntabililtas, (3) Responsibilitas, (4) Independensi, (5) Keadilan. Dengan adanya kelima prinsip tersebut akan meminimalkan tindakan fraud dalam Perguruan Tinggi, karena mekanisme GUG akan memunculkan suatu skema pengawasan dan pertanggungjawaban terhadap pengelolaan PT.

Implementasi GUG tidak lepas dari Peran Satuan Pengawasan Intern, SPI merupakan fungsi staf yang melakukan penilaian secara bebas atau tidak memihak dalam suatu organisasi untuk memeriksa dan mengevaluasi seluruh aktivitas dan melaporkan hasil pekerjaannya tersebut kepada manajemen sebagai suatu jasa pelayanan, dan bertanggung jawab penuh kepada manajemen.

Setiap perguruan tinggi pasti mempunyai Satuan Pengawasan Intern untuk melakukan aktivitas audit yang lebih mengarah pada kegiatan review dan aktifitas konsultasi. Sehingga pengelolaan universitas yang baik juga terletak dari peran SPI untuk menerapkan prinsip-prinsip GUG.

Penelitian yang berkaitan dengan Good University Governance telah banyak dilakukan yaitu Rosyid (2014) dengan judul Survey Atas Implementasi Good University Governance (Studi Kasus STAIN Pekalongan) yang memiliki 5 prinsip yaitu akuntabilitas, responsiveness, budaya akademik, mutu layanan akademik dan prakarsa. Dengan metode analisis uji beda dan menghitung nilai rata-rata score prinsip GUG, yang menyimpulkan hasil bahwa implementasi GUG di STAIN Pekalongan masih dalam kategori sedang.

Baihaki (2016) dengan judul Persepsi Mahasiswa Terhadap Tata Kelola Universitas Lampung (Good University Governance), yang menggunakan enam prinsip GUG yaitu transparansi, akuntabilitas, indepedensi dan partisipasi responden menilai positif dan indikator responsibilitas dan kewajaran menilai negatif pelaksanaanya.

Penelitian Christensen (2011) dengan judul reformasi tata kelola perguruan tinggi, terkait masalah otonomi. Sebab universitas juga menghasilakan sebuah laporan, sistem pengawasan dan pengendalian, dan sistem insentif keuangan Analisis didasarkan pada pendekatan transformasional dari teori organisasi, yang mewakili kombinasi faktor struktural, budaya dan lingkungan dalam proses reformasi serta dampaknya.

Selain itu kaitannnya Good University Governance dengan Satuan Pengawasan Intern pernah dilakukan oleh Untari (2015) Penelitian mengenani Pengaruh Peran Satuan Pengawasan Intern (SPI) dan Penerapan Internal Control Tehadap Good University Governance dengan menemukan hasil bahwa Satuan Pengawasan Intern dan Internal Control berpengaruh terhadap Good University Governance.

Prinsip-prinsip GUG telah banyak dikembangkan oleh 
peniliti dari dalam hingga luar negeri, dengan membagi aspek GUG dalam jumlah yang berbeda, serta dengan model yang berbeda pula. Prinsip GUG oleh Wijatno (2009) menjadi dasar pemilihan prinsip yang penulis gunakan dalam penelitian ini, dengan kelima prinsip yaitu Transparansi, Akuntabililtas, Responsibilitas, Independensi, dan Keadilan.

Transparansi merupakan ketersediaan informasi yang cukup, akurat, dan tepat waktu tentang kebijakan publik dan proses pembentukannya serta menjamin akses bagi setiap orang untuk memperoleh informasi. Menurut Wijatno (2009) Universitas harus dan dapat menerapkan prinsip keterbukaan di bidang keuangan, sistem dan prosedur penerimaan mahasiswa baru, sistem dan prosedur akuntansi, pelaporan keuangan, rekruitmen dosen dan karyawan, pemilihan pejabat structural, pemilihan pengurus dan informasi-informasi penting lainnya kepada pemangku kepentingan secara memadai, akurat dan tepat waktu.

Menurut Krina (2003) Akuntabilitas adalah prinsip yang menjamin bahwa setiap kegiatan penyelenggaraan pemerintahan dapat dipertanggungjawabkan secara terbuka oleh pelaku kepada pihak-pihak yang terkena dampak penerapan kebijakan. Peters (2000) menyebutkan adanya 3 tipe akuntabilitas yaitu: (1) akuntabilitas keuangan, (2) akuntabilitas administratif, dan (3) akuntabilitas kebijakan publik.

Responsibilitas yaitu merupakan sejauh mana kebijakan, regulasi, dan pengalokasian anggaran mendapat dukungan dan tanggapan positif dari sivitas akademika. Kesesuai didalam pengelolaan organisasi terhadap peraturan perundang-undangan yang berlaku. Setiap individu yang berkaitan dalam pengelolaan universitas harus bertanggung jawab atas segala tindakannya sesuai dengan tugas fungsi yang telah ditetapkan. (Djanali, 2005)

Independensi merupakan keadaan dimana organisasi dikelola secara profesional tanpa benturan kepentingan dan pengaruh tekanan dari pihak manapun yang tidak sesuai dengan peraturan perundang- undangan yang berlaku serta menerapkan prinsip-prinsip oraganisasi yang sehat. (Zarkasyi, 2008)

Sedangkan keadailan berkaitan dengan perlakuan yang adil dan berimbang kepada para pemangku kepentingan yang terkait. Dalam hal ini, para pemangku kepentingan terdiri atas mahasiswa, masyarakat, para dosen, dan karyawan non-akademis, serta pengurus yayasan.

Kelima prinsip GUG mempunyai indicator masing-masing untuk menentukan apakah tata kelola perguruan tinggi sudah dilaksankan secara optimal. Tidak menutup kemungkinan dari prinsip-prinsip yang ada hanya ada satu prinsip yang menjadi prioritas dalam sebuah perguruan tinggi.

Oleh karena itu diperlukan metode yang bisa menunjukan prinsip GUG yang menjadi prioritas perguruan tinggi. Salah satu metode yang bisa digunakan untuk pemilihan prinsip prioritas GUG adalah metode AHP (Analytical Hierarchy Process). Metode ini menyertakan ukuran-ukuran kualitatif dan kuantitatif. AHP adalah metode pengambilan keputusan yang dikembangkan untuk pemberian prioritas beberapa alternative ketika beberapa kriteria harus dipertimbangkan, serta mengijinkan pengambil keputusan untuk menyusun masalah yang kompleks ke dalam suatu bentuk hirarki atau serangkaian level yang terintegrasi.

AHP relatif mudah dimengerti dan digunakan. AHP adalah sebuah metode yang ideal untuk memberikan ranking/urutan alternatif ketika beberapa kriteria dan subkriteria ada dalam pengambilan keputusan.

Berdasarkan latar belakang diatas maka peniliti tertarik untuk mengetahui urutan prioritas dalam pengimplentasian Good University Governance pada Perguruan Tinggi yang ada di Kota Jayapura, serta mencari Perguruan Tinggi yang telah menerpakan GUG melalui tesis yang berjudul "ANALISIS PENERAPAN GOOD UNIVERSITY GOVERNANCE PADA PERGURUAN TINGGI DI KOTA JAYAPURA".

Perumusan masalah dalam penelitian ini adalah: 1) Bagaimana Model Good University Governance di Perguruan Tinggi Kota Jayapura? 2) Apakah Good University Governance sudah diterapkan pada perguruan tinggi di Kota Jayapura? dengan tujuan untuk 1) mengetahui dan menganalisis Model Good University Governance di Perguruan Tinggi Kota 
Jayapura, 2) Untuk mengetahui dan menganalisis penerapan Good University Governance pada Perguruan tinggi Kota Jayapura.

\section{Tinjauan Pustaka}

\subsection{Stewarship Theory}

Dasar teori yang digunakan dalam penelitian ini adalah teori tata laksana (Stewarship theory). Teori ini memandang manajemen sebagai pihak yang dapat dipercaya untuk bertindak dengan sebaik-baiknya bagi kepentingan public pada umumnya maupun shareholders pada khususnya.

Teori stewardship dapat diterapkan pada penelitian akuntansi sektor public seperti organisasi pemerintahan salah satunya pada Perguruan Tinggi. Akuntansi organisasi sektor publik telah dipersiapkan untuk memenuhi kebutuhan informasi bagi hubungan antara stewards dengan principals. Akuntansi sebagai penggerak (driver) berjalannya transaksi bergerak kearah yang semakin kompleks dan diikuti dengan tumbuhnya spesialisasi dalam akuntansi dan perkembangan organisasi sektor publik. Kondisi semakin kompleks dengan bertambahnya tuntutan akan akuntabilitas pada Perguruan Tinggi yang ada di Indonesia.

Teori ini mengasumsikan hubungan yang kuat antara kesuskesan organisasi dengan kepuasan pemilik. Steward akan melindungi dan memaksimalkan kekayaan organisasi dengan kinerja perusahaan, sehingga dengan demikian fungsi utilitas akan maksimal. Asumsi penting dari stewardship adalah manajer meluruskan tujuan sesuai dengan tujuan pemilik. Namun demikian tidak berarti steward tidak mempunyai kebutuhan hidup. (Raharjo, 2007)

Dalam penelitian ini teori stewarship menjadi hal penting pada pencapaiam Good Univeristy Governance. Sebab pada hakikatnya manusia diharapkan dapat dipercaya, mampu bertndak dengan penuh tanggung jawab, memiliki integritas dan kejujuran terhadap pihak lain. Transparansi dan akuntabilitas mempunyai peran besar untuk menujukkan kepada pihak eksternal yaitu pemerintahan dan masyarakat bahwa pengelolaan perguruan tinggi sudah berjalan dengan baik. Dengan mengedapankan kepentingan bersama serta komitmen organisasi yang optimal agar tercapai tujuan yang diharapkan.to

\subsection{Perguruan Tinggi}

Pengertian Perguruan Tinggi menuut PP Nomor 60 Tahun 1999, adalah sebagai satuan pendidikan dengan wilayah otonom dan mandiri yang berhak mengelola sendiri lembaganya sebagai pusat penyelenggaraan pendidikan tinggi penekanan ilmiah dan pengabdian masyarakat. Adapun maksud tujuan pemberian otonomi tersebut diberikan dalam rangka pengembangan ilmu pengetahuan dan teknologi, pengembangan diri para civitas academica, serta berpedoman pada norma dan kaidah keilmuan itu sendiri.

Perguruan tinggi menurut Ketentuan Peraturan Menteri Pendidikan Nasional Republik Indonesia Nomor 32 Tahun 2009 tentang mekanisme Pendirian Badan Hukum, Perubahan Badan Hukum Milik Negara atau Perguruan Tinggi dan Pengakuan Penyelengaraan Pendidikan Tinggi sebagai Badan Hukum Pendidikan adalah Perguruan Tinggi yang diselenggarakan oleh pemerintah atau masyarakat.

Menurut Undang-Undang Nomor 12 Tahun 2012 Tentang Pendidikan diartikan sebagi pendidikan yang dilaksanakan setelah pendidikan menengah yang mencakup program pendidikan diploma, sarjana, magister, spesialis, dan doktor yang di selenggarakan oleh perguruan tinggi. Pendidikan tinggimenjadi sumber inovasi dan solusi bagi pertumbuhan dan perkembangan bangsa seiring dengan berkembangnya zaman.

\subsection{Pengelolaan Perguruan Tinggi}

Tata kelola merupakan suatu kondisi yang menjamin adanya proses kesejajaran, kesamaan, kohesi, dan keseimbangan peran, serta adanya salingmengontrol yang dilakukan oleh komponen terkait. Secara teknis tata kelola dinyatakan sebagai upaya sistematis dalam suatu proses untuk mencapai tujuan organisasi, melalui fungsi-fungsi perencanaan, pelaksanaan, pengendalian, dan tindak lanjut peningkatan. Dengan demikian, tata kelola selain melingkupi seluruh proses dan 
unsur-unsur tersebut, juga memiliki tujuan utama yaitu peningkatan kualitas PT secara terus menerus untuk mencapai visi dan misi yang ditetapkan. Untuk saat ini pengelolaan perguruan tinggi ada dalam berapa pasal dalam Undang-undang No 12 Tahun 2012.

\subsection{Good University Governance}

Menurut Price Waterhouse Coopers dalam (Yuwono, 2011) yang menyatakan bahwa Corporate Governance terkait dengan pengambilan keputusan yang efektif, dibangun melalui kultur organisasi, nilai-nilai, , berbagai proses, kebijakan-kebijakan dan struktur organisasi, yang bertujuan untuk mencapai bisnis yang menguntungkan, efisien, dan efektif dalam mengelola risiko dan bertanggung jawab dengan meperhatikan kepentingan stakeholder.

Sedangkan Good University Governance (GUG) menurut Wijatno (2009:126), dapat dipandang sebagai penerapan prinsip-prinsip dasar konsep "good governance" dalam sistem dan proses governance pada institusi perguruan tinggi melalui berbagai penyesuaian yang dilakukan berdasarkan nilai-nilai yang harus dijunjung tinggi dalam penyelenggaraan perguruan tinggi secara khusus dan pendidikan secara umum.

Berdasarkan definisi diatas, dapat disimpulkan bahwa Good University Governance (GUG) merupakan bagian dari Good Governance yang penyelenggaraannya di dunia pendidikan yaitu perguruan tinggi.

Good University Governance (GUG) merupakan suatu konsep yang menerapkan prinsip-prinsip dasar Good Governance seperti transparansi, akuntabilitas, responsibilitas, independensi, dan keadilan yang perlu diterapkan oleh setiap perguruan tinggi untuk mewujudkan perguruan tinggi yang berkualitas.

Menurut Wijatno (2009), pencapaian GUG dapat diukur melalui beberapa indikator yaitu transparansi, akuntabilitas, responsibilitas, independensi dan kewajaran.

a. Transparansi

Transparansi dibangun atas dasar arus informasi yang bebas. Seluruh proses pemerintahan, lembaga-lembaga, dan informasi perlu dapat diakses oleh pihak-pihak yang berkepentingan dan informasi yang tersedia harus memadai agar dapat dimengerti dan dipantau.

Menurut Andrianto (2007) "Keterbukaan secara sungguh-sungguh, menyeluruh, dan memberi tempat bagi partisipasi aktif dari seluruh lapisan masyarakat dalam proses pengelolaan sumber daya publik."

Prinsip transparasi paling tidak dapat diukur melalui sejumlah indikator seperti: (Krina, 2003)

a. mekanisme yang menjamin sistem keterbukaan dan standarisasi dari semua proses-proses pelayanan public

b. mekanisme yang memfasilitasi pertanyaan-pertanyaan publik tentang berbagai kebijakan dan pelayanan publik, maupun proses-proses didalam sektor publik.

c. mekanisme yang memfasilitasi pelaporan maupun penyebaran informasi

d. maupun penyimpangan tindakan aparat publik didalam kegiatan melayani

Sedangkan menurut Wijatno (2009) dalam mengukur transparansi pada pengelolaan perguruan tinggi harus dan dapat menerapkan prinsip keterbukaan di bidang keuangan, sistem dan prosedur penerimaan mahasiswa baru, sistem dan prosedur akuntansi, pelaporan keuangan, rekruitmen dosen dan karyawan, pemilihan pejabat structural, pemilihan pengurus dan informasi-informasi penting lainnya kepada pemangku kepentingan secara memadai, akurat dan tepat waktu.

b. Akuntabilitas

Universitas harus mempunyai uraian tugas dan tanggung jawab yang jelas (tertulis) dari pejabat struktural. Kriiterian dan proses pengukuran kinerja, pengawasan dan pelaporan harus ada audit internal dalam rangka penilaian kerja untuk tujuan mengevaluasi dan mengendalaikan aktivitas organisasi. (Baihaki, 2016).

Menurut Krina (2003) Akuntabilitas adalah prinsip yang menjamin bahwa setiap kegiatan penyelenggaraan pemerintahan dapat dipertanggungjawabkan secara terbuka oleh pelaku kepada pihak-pihak yang terkena dampak penerapan kebijakan. Krina menjelaskanindikator-indikator akuntabilitas sebagai berikut: 
1. Mampu menyajikan informasi penyelenggaraan kegiatan secara terbuka, cepat dan tepat kepada masyarakat.

2. Mampu memberikan pelayanan yang memuaskan bagi publik.

3. Mampu menjelaskan dan mempertanggung jawabkan setiap kebijakan yang diambil secara proporsional.

4. Penyebarluasan informasi mengenai suatu keputusan melalui media massa

5. Akses publik pada informasi atas suatu keputusan setelah keputusan dibuat dan mekanisme pengaduan masyarakat.

Akuntabilitas (accountability) menurut Wijatno (2009) Universitas harus mempunyai uraian tugas dan tanggung jawab yang jelas (secara tertulis) dari setiap pejabat struktural, anggota senat fakultas/akademis, pengurus yayasan, dosen dan karyawan termasuk juga kriteria dan proses pengukuran kinerja, pengawasan, dan pelaporan. Harus ada audit internal yang tugasnya antara lain: melakukan penilaian analisis dan interpretasi dari aktivitas suatu organisasi secara independen. Pada dasarnya ruang lingkup audit internal mencakup aspek kegiatan dalam organisasi dalam rangka penilaian kinerja untuk tujuan mengevaluasi dan mengendalikan aktivitas organisasi dapat dicapai dengan efisien dan efektif. Selain itu ada baiknya juga dilakukan manajemen audit atau financial audit plus oleh pihak ekstern yang independen.

c. Responsibilitas

Responsibilitas merupakan kemampuan organisasi untuk mengatur sejauhmana pemberian layanan telah berjalan sesuai dengan aturan-aturan yang diberlakukan atau prosedur yang telah di atur. Responsibilitas mengukur tingkat pastisipasi pemberi layanan melaksanakan tugasnya. Responsibilitas adalah ukuran yang menunjukkan sejauh mana proses pemberian pelayanan publik dilakukan sesuai dengan prinsip-prinsip atau ketentuan-ketentuan administrasi dan organisasi yang benar telah ditetapkan. (Muslimah, 2016)

Menurut Djanali (2005) indikator yang dapat digunakan yaitu:

1. Membangun suasana akademik yang kondusif.

2. Memanfaatkan dana dengan kehati-hatian sesuai dengan tujuan pemberi dana.

3. Menghasilkan inovasi untuk pengembangan ekonomi.

4. Menjamin kebebasan akademis bagi seluruh staff dalam memberikan masukan sesuai dengan keahliannya

5. Membentuk profesional-profesional atau disiplin ilmu yang dibutuhkan oleh masyarakat sebagai keunggulan dari universitas.

Responsibilitas (responsibility) menurut Wijatno (2009) mencerminkan kepatuhan terhadap peraturan perundang-undangan serta pelaksanaan tanggung jawab terhadap masyarakat dan lingkungan sehingga dapat terpelihara kesinambungan usaha dalam jangka panjang. Setiap individu yang terlibat dalam pengelolaan universitas harus bertanggung jawab atas tindakannya sesuai dengan job description yang telah ditetapkan.

d. Independensi

Menurut Zarkasyi (2008) Keadaan dimana organisasi dikelola secara profesional tanpa benturan kepentingan dan pengaruh tekanan dari pihak manapun yang tidak sesuai dengan peraturan perundang-undangan yang berlaku serta menerapkan prinsip-prinsip oraganisasi yang sehat. Pengelola universitas dalam melaksanakan peran dan tanggung jawab harus bebas dari bentuk intervensi dari pihak manapun. Hal ini untuk memastikan keputusan yang diambil bebas dari tekanan dan dibuat hanya untuk kepentingan universitas.

Indikator yang dapat digunakan yaitu:

a. Pengambilan keputusan perguruan tinggi perlu terpisah dari pemerintah atau badan hukum nirlaba yang memilikinya sehingga terbebas dari benturan kepentingan didalamnya.

b. Menghindari terjadinya dominasi oleh pihak manapun.

c. Melaksanakan tugas dan fungsi sesuai dengan anggaran dasar dan peraturan perundang-undangan. Independensi (independency) menurut Wijatno (2009), pihak yayasan dan pengelola universitas 
dalam melaksanakan peran dan tanggung jawabnya harus bebas dari segalan benturan kepentingan yang berpotensi untuk muncul. Hal ini diperlukan untuk memastikan bahwa pengambilan keputusan dilakukan secara independen, bebas dari segala bentuk tekanan dari pihak lain, sehingga dapat dipastikan bahwa keputusan itu dapat dibuat demi kepentingan universitas.

e. Kewajaram

Fairness adalah keadilan terhadap stakeholder agar setiap stakeholders terlindungi dari upaya penyelewengan baik dalam bentuk usaha untuk kepentingan pribadi maupun benturan kepentingan atau praktik universitas yang tidak sehat. Terkait dengan mahasiswa, praktik fairness dapat dilihat dari adanya skema subsidi dan alokasi biaya pendidikan untuk mahasiswa kurang mampu. (Anggriwan \& Nurcholis, 2014)

Menurut Direktorat Kelembagaan dan Kerjasama Ditjen Dikti Kemdikbud (2014) dalam Muktiyanto (2016), fairness dapat dilakukan melalui antara lain; (1) pengangkatan pegawai dan pejabat berdasarkan kompetensi dan track record, dan (2) penerapan merit system (insentif dan dis-insentif) yang tepat dalam pengelolaan pegawai. Dalam hal merit system dapat diukur dari adanya key performance indicator dalam menilai kinerja yang menjadi dasar penilaian kinerja. Selain itu dapat dilihat dari adanya sistem remunerasi dan penerapannya termasuk menjadi dasar penghargaan bagi staf. Berkaitan dengan hubungan antara Program Studi dan Fakultas dapat dilihat melalui keterwakilan Program Studi pada Senat Fakultas dan keefektivitasannya.

Menurut Zarkasyi (2008) indicator yang dapat digunakan yaitu:

a. Universitas memberikan perlakuan yang setara dan wajar kepada pihak yang berkepentingan sesuai dengan manfaat dan kontribusi yang diberikan kepada universitas.

b. Universitas memberikan kesempatan yang sama dalam penerimaan karyawan, mahasiswa, berkarir dan melaksanakan tugasnya secara profesional tanpa adanya diskriminasi

c. Penerapan reward dan Punishment kesemua pihak tanpa adanya diskriminasi.

Sedangkan Keadilan (fairness) menurut (Wijatno, 2009) Perlakuan yang adil dan berimbang kepada para pemangku kepentingan yang terkait. Dalam hal ini, para pemangku kepentingan terdiri atas mahasiswa, masyarakat, para dosen, dan karyawan non-akademis, serta pengurus yayasan.

\subsection{Analytical Hierarchy Process (AHP)}

Analytical Hierarchy Process (AHP) dikembangkan oleh Thomas L. Saat pada tahun 1970-an. Metode ini merupakan salah satu model pengambilan keputusan multi kriteria yang dapat membantu kerangka berpikir manusia di mana faktor logika, pengalaman, pengetahuan, emosi, dan rasa dioptimasikan ke dalam suatu proses sistematis. AHP adalah metode pengambilan keputusan yang dikembangkan untuk pemberian prioritas beberapa alternatif ketika beberapa kriteria harus dipertimbangkan, serta mengijinkan pengambil keputusan (decision makers) untuk menyusun masalah yang kompleks ke dalam suatu bentuk hirarki atau serangkaian level yang terintegrasi. Pada dasarnya, AHP merupakan metode yang digunakan untuk memecahkan masalah yang kompleks dan tidak terstruktur ke dalam kelompok-kelompoknya, dengan mengatur kelompok tersebut ke dalam suatu hirarki, kemudian memasukkan nilai numerik sebagai pengganti persepsi manusia dalam melakukan perbandingan relatif. Dengan suatu sintesis maka akan dapat ditentukan elemen mana yang mempunyai prioritas tertinggi.

\subsection{Penelitian Terdahulu}

Penelitian terkait Good University Governance telah banyak dilakukan, yaitu oleh Muktiyanto (2016) dengan judul "Good University Governance Dan Kinerja Programstudi: Pengaruh Penerapan Akuntansi Manajemen, Teknik manajemen, Dan Pilihan Prioritas Strategi Sebagai model mediasi Fit “. Teori kontinjensi menyebutkan bahwa konteks yang berbeda akan menghasilkan kinerja yang berbeda. Penelitian atas 231 Program Studi Akuntansi di Indonesia ini dengan 
menggunakan Struktural Equation Model dan pendekatan mediasi fit membuktikan adanya peran konteks tersebut. Penelitian ini memberikan bukti empiris bahwa hubungan GUG dan kinerja dipengaruhi oleh penerapan akuntansi manajemen, penerapan teknik manajemen dan pilihan prioritas strategi sebagai mediasi fit. Terjadi keragaman pengaruh GUG terhadap kinerja beserta mediasinya baik dari signifikansi, besaran, maupun arah hubungan yang ditentukan oleh konteks: PTN, PTS, dan PTS berakreditasi A dan B secara khusus dan sektor publik secara umum

Baihaki (2016) Persepsi Mahasiswa Terhadap Tata Kelola Universitas Lampung (Good University Governance) Penelitian ini menggunakan metode kuantitatif deskriptif. Teknik penentuan sampel dalam penelitian ini adalah purposive sampling. data yang terkumpul berasal dari pembagian kuesioner sebanyak 95 responden yang merupakan mahasiswa aktif di delapan fakultas di Unila, di perjelas dengan hasil wawancara mendalam dengan beberapa tokoh mahasiswa di lingkungan Universitas lampung. Penilaian responden terhadap enam indikator konsep good university governance, untuk indikator transparansi, akuntabilitas, indepedensi dan partisipasi responden menilai positif dan indikator responsibilitas dan kewajaran menilai negatif pelaksanaanya. Secara keseluruhan persepsi mahasiswa terhadap tata kelola universitas lampung menunjukan persepsi positif.

Suryani (2015) dengan judul "Good University Governance" yang menyimpulkan bahwa Salah satu upaya peningkatan kualitas pendidikan dapat dilakukan dengan penerapan tata kelola yang baik di perguruan tinggi atau good university governance. Konsep Good University Governance (GUG) adalah sistem perguruan tinggi dan pendidikan tinggi menetapkan tujuan, menerapkan, mengelola institusi mereka baik secara fisik, keuangan, sumber daya manusia, akademik, maupun prestasi mahasiswa.

Ganga, Quiroz, \& Fossatti (2017) dengan judul penelitian "A synchronic analysis of university governance: a theoretical view of the sixties and seventies". Penelitian ini bertujuan untuk menganalisis konsep pemerintahan dan konsep perguruan tingg dengan metologi menggunakan data sekunder. Hasil penelitian menunjukkan bahwa lapisan akademis dalam kemunculan perguruan tinggi menjadi peran yang penting dalam tata kelola perguruan tinggi, sehingga akan menciptkan sistem manajemen yang baik. Serta legitimasi yang diberikan oleh masyarakat menjadi awal strategi dalam bidang pengelolaan.

Rosyid (2014) dengan judul Survei Atas Implementasi Good University Governance (Studi Kasus STAIN Pekalongan) dengan memilih tiga responden yaitu mahasiswa, staf dan dosen, serta menggunakan analisis uji beda non-parametric. Penelitian ini menemukan hasil bahwa (1) hasil rata-rata total yang ditempatkan antara 7,34 sampai 9,89 yang berarti bahwa variabel penelitian berada pada tingkat menengah (2) persepsi dosen berbeda secara signifikan dengan persepsi mahasiswa terkait implementasi Good University Governance.

Christensen (2011) dengan judul "University governance reforms: potential problems of more autonomy" dengan pemikiran bahwa Reformasi tata kelola universitas sangat banyak mencerminkan reformasi Manajemen Publik Baru yang lebih luas yang berfokus pada peningkatan efisiensi dalam organisasi publik. Analisis didasarkan pada pendekatan transformasional dari teori organisasi, yang mewakili kombinasi faktor struktural, budaya dan lingkungan dari penjelasan untuk proses reformasi dan pengaruhnya. Secara empiris artikel ini didasarkan pada studi empiris penulis sendiri tentang reformasi universitas dan ulasan studi komparatif.

\subsection{Kerangka Analisis}

Perguruan tinggi sebagai jenjang pendidikan tertinggi dalam sistem pendidikan formal dinegara kita, yang nantinya dituntut dapat menghasilkan tenaga-tenaga ahli profesional dibidangnya dan berdaya saing tinggi. Adapun konsep yang saat ini menjadi penting dalam penyelenggaraan perguruan tinggi adalah konsep good university governance. Konsep ini merupakan konsep turunan dari konsep good corporate governance (GCG) yang berawal dari tata pemerintahan yang baik yaitu Good Governance. (Baihaki, 2016)

Penelitian ini, memfokuskan pada pembahasan 
mengenai penerapan GUG di Perguruan Tinggi Kota Jayapura. Dengan berdasarkan 5 aspek menurut Wijatno (2009) yaitu transparansi, akuntabilitas, responsibility, indpendensi dan kewajaran dengan memiliki indiktaror atau subkrteria masing-masing. Penelitian ini mengarah pada pengembangan Model GUG dengan menggunakan Analitical Hirarki Proses (AHP) yang terdiri dari criteria dan subkriteria, kemudian akan menghasilkan model Good University Governance dengan melihat tingkat implementasi GUG pada Perguruan tinggi di Kota Jayapura. Dengan menggunakan metode kuesioner dan wawancara (justifikasi).

Berdasarkan uraian diatas, maka kerangka pemikiran penelitian ini dapat digambarkan sebagai berikut:

\section{Metode Penelitian}

\subsection{Desain Penelitian}

Desain penelitian adalah rencana dari struktur penelitian yang mengarahkan proses dan hasil penelitian sedapat mungkin menjadi valid, obyektif, efisien, dan efektif. (Jogiyanto, 2004)

Penelitian yang dilakukan adalah penelitian studi kasus (case study design). Studi kasus meliputi analisis mendalam dan kontekstual terhadap situasi yang mirip dalam organisasi lain, di mana sifat dan definisi masalah yang terjadi adalah serupa dengan yang dialami dalam situasi saat ini. Penelitian ini dilakukan pada beberapa perguruan tinggi di Kota Jayapura.

\subsection{Populasi dan Sampel Populasi}

Populasi adalah wilayah generalisasi yang terdiri dari objek atau subjek yang mempunyai kualitas dan karakteristik yang ditetapkan oleh peneliti untuk dipelajari kemudian ditarik kesimpulan. Populasi dari penelitian ini adalah Perguruan Tinggi di Kota Jayapura.

\section{Sampel}

Sampel adalah sebagian dari populasi yang terdiri atas sejumlah anggota yang dipilih dari populasi. Teknik pengambilan sampel dilakukan dengan

Non-random sampling, yaitu dengan Three Stage Sampling terdiri dari Stratified Sampling, Cluster
Sampling dan Purposive Sampling.

Pentuan responden dilakukan dengan dua cara yaitu Cluster Sampling dan Stratified Sampling. Cluster Sampling adalah teknik sampling secara berkelompok. Peengambilan sampel jenis ini berdasarkan kelompok/area tertentu. Pada penelitian ini sampel dipilih berdasarkan Perguruan tinggi di kota Jayapura, yaitu langsung mengarah pada 4 perguruan tinggi dengan beberapa fakultas pilihan:

a. Universitas Cenderawasih Papua

b. Universitas Sains dan Teknologi Jayapura

c. Sekolah Tinggi Ilmu Ekonomi Port Numbay

d. Universitas Yayasan Pendidikan Islam

Stratified Sampling adalah metode pengambilan sampel berdasarkan tingkatan tertentu yaitu mengarah pada civitas akademik di perguruan tinggi yaitu:
a. Dekan
b. Pembantu Dekan 1,2,3
c. Staf TU
d. Bagian Kemahasiswaan
e. Bagian Akademik
f. Ketua Jurusan
g. Ketua Program Studi
h. Dosen
i. Mahasiswa

Sedangkan purposive sampling dilakukan untuk menentukan informan dalam menentukan model GUG melalui Analitical Hierarcy Proses yaitu, Anggota Satuan Pengawasan Intern. Berdasarkan Kepakaran dalam pengawasan perguruan tinggi. Menurut Permendikbud No.47 Tahun 2011, Dalam menjalankan tugas sebagaimana dimaksud pada pasal 3, SPI di Perguruan Tinggi menyelanggarakan fungsi sebagai berikut:

a. Penyusunan program pengawasan

b. Pengawasan kebijakan dan program

c. Pengawasan pengelolaan kepegawaian, keuangan dan barang milik Negara;

d. Pemantauan dan pengkoordinasian tindak lanjut hasil pemeriksaan internal dan eksternal;

e. Pendampingan dan reviu laporan keuangan

f. Pemberian saran dan rekomendasi

g. Penyusunan laporan hasil pengawasan dan 
h. Pelaksanaan evaluasi hasil pengawasan

\section{Sumber Data}

Sumber penelitian ini mengguanakan data Primer. Data Primer merupakan data yang diperoleh dari sumber pertama baik dari individu atau perseorangan, seperti hasil wawancara atau hasil pengumpulan kuesioner (Sekaran, 2006). Data primer dalam penelitian ini diperoleh dari wawancara dan kuesioner yang dibagikan kepada responden.

\section{Metode Pengumpulan Data}

a. Kuesioner

Kuesioner adalah daftar pertanyaan tertulis yang telah dirumuskan sebelumnya yang akan responden jawab, biasanya dalam alternatif yang didefinisikan dengan jelas (Sekaran, 2006). Bentuk kuesioner yang digunakan dalam penelitian ini mengacu pada contoh kuesioner dalam Saaty, 1994. Sedangkan item-item yang dibandingkan dalam kuesioner adalah aspek atau prinsip dari Good University Governance. Kuesioner ini dibagikan kepada para responden.

b. Wawancara adalah teknik pengumpulan data dengan mengajukan pertanyaan langsung oleh pewawancara kepada pihak perusahaan, dan jawaban-jawaban responden dicatat atau direkam. Wawancara yang digunakan dalam penelitian ini adalah wawancara terstruktur. Wawancara terstruktur yaitu wawancara dimana pewawancara memiliki daftar pertanyaan yang ditujukan pada pihak perusahaan

\section{Definisi Operasional dan Pengukuran}

Berdasarkan prinsip Good University Governance menurut (Wijatno, 2009), bahwa GUG yang dibagi menjadi 5 prinsip yaitu:

a. Transparansi

Transparansi dibangun atas dasar arus informasi yang bebas. Seluruh proses pemerintahan, lembaga-lembaga, dan informasi perlu dapat diakses oleh pihak-pihak yang berkepentingan dan informasi yang tersedia harus memadai agar dapat dimengerti dan dipantau. Transparansi memiliki 3 sub criteria yaitu:

(1) Dilakukannya sosialisasi tentang rencana strategis yang telah dikembangkan kepada sivitas akademik.

(2) Keterbukaan dibidang keuangan, sistem dan prosedur penerimaan mahasiswa baru, sistem akuntansi, sistem pelaporan, rekrutmen dosen dan karyawan serta pemilihan pejabat structural

(3) Kebijakan diperguruan tinggi didokumentasikan dan dikomunikasikan kepada pihak intern maupun ekstern perguruan tinggi.

\section{b. Akuntabilitas}

Budiardjo (1998) mendefinisikan akuntabilitas sebagai"pertanggungjawaban pihak yang diberi mandat untuk memerintah kepada mereka yang memberi mandat itu. Akuntabilitas memilik 3 sub criteria yaitu:

(1) Perguruan tinggi tempat Bapak/Ibu bekerja memiliki uraian, tugas dan tanggung jawab yang jelas dari setiap pejabat structural, anggota senat fakultas/akademis, dosen dan karyawan yang selaras dengan visi, dan rencana strategis.

(2) Sistem pengendalian intern dilakukan secara efektif dalam pengelolaan perguruan tinggi.

(3) Pengukuran kinerja untuk tujuan mengevaluasi dan mengendalikan aktivitas organisasi dapat dicapai dengan efisien dan efektif.

c. Responsibilitas

Responsibilitas merupakan kemampuan organisasi untuk mengatur sejauhmana pemberian layanan telah berjalan sesuai dengan aturan-aturan yang diberlakukan atau prosedur yang telah di atur. Responsibiltas memilik 2 sub criteria yaitu:

(1) Kepatuhan terhadap peraturan perundang-undangan yang berlaku tentang penyelenggaarn perguruan tinggi

(2) Kepatuhan terhadap peraturan perundang-undangan yang dibuat.

(3) Pelaksanaan tanggung jawab terhadap masyarakat dan lingkungan sehingga dapat terpelihara kesinambungan usaha dalam jangka panjang 


\section{d. Independensi}

Menurut Zarkasyi (2008) Keadaan dimana organisasi dikelola secara profesional tanpa benturan kepentingan dan pengaruh tekanan dari pihak manapun yang tidak sesuai dengan peraturan perundang-undangan yang berlaku serta menerapkan prinsip-prinsip oraganisasi yang sehat. Independensi memiliki sub criteria yaitu:

(1) Pengambilan keputusan perguruan tinggi perlu terpisah dari pemerintah yang memilikinya sehingga terbebas dari benturan kepentingan didalamnya.

(2) Menghindari terjadinya dominasi oleh pihak manapun.

(3) Pelaksanaan tugas dan fungsi dalam perguruan tinggi bebas dari segala pengaruh dan tekanan yang bersifat intern dan ekstern

\section{e. Keadilan}

Kewajaran atau Fairness adalah keadilan terhadap stakeholders agar setiap stakeholders terlindungi dari upaya penyelewengan baik dalam bentuk usaha untuk kepentingan pribadi maupun benturan kepentingan atau praktik universitas yang tidak sehat. Kewajaran memiliki 3 sub criteria yaitu:

(1) perlakuan yang setara dan wajar kepada pihak yang berkepentingan sesuai dengan manfaat dan kontribusi yang diberikan kepada universitas.

(2) Diberikan kesempatan yang sama dalam penerimaan karyawan, mahasiswa, berkarir dan melaksanakan tugasnya secara profesional tanpa adanya diskriminasi.

(3) Penerapan reward dan Punishment kesemua pihak tanpa adanya diskriminasi

\section{Metode Analisis Data}

Analisis data yang digunakan dalam penelitian ini adalah metode AHP (Analytical Hierarchy Process).

Pemodelan Good University Governance

$\mathrm{GUG}=\alpha 1 \mathrm{~T}+\alpha 2 \mathrm{~A}+\alpha 3 \mathrm{R}+\alpha 4 \mathrm{I}+$ $\alpha 5 \mathrm{~K}$

Sehingga dari pemodelan GUG akan menghasilkan kategori penerapan Good University Governance pada masing-masing perguruan tinggi di Kota Jayapura. Kategori tersebut adalah sebagai berikut:

\section{Hasil dan Pembahasan}

\subsection{Pengumpulan Data}

Pengumpulan data pada penelitian ini diperoleh dengan dua cara, pertama dengan menyebarkan kuesioner kepada responden dengan mendatangi langsung lokasi pengambilan sampel yaitu civitas akademik pada Perguruan Tinggi di Kota Jayapura, yaitu Universitas Cenderawasih (UNCEN), Universitas Yapis Papua (UNIYAP), Universitas Sains dan Teknologi Jayapura (USTJ), dan Sekolah Tinggi Ilmu Ekonomi Port Numbay Jayapura. Kedua dengan menyebarkan kuesioner AHP kepada beberapa anggota SPI Perguruan Tinggi Indoneisa.

Tabel 4.1

Lokasi dan Daftar Distribusi Kuesioner

\begin{tabular}{|c|l|c|}
\hline No & \multicolumn{1}{|c|}{ Lokasi } & $\begin{array}{c}\text { Jumlah } \\
\text { Kuesioner }\end{array}$ \\
\hline 1 & $\begin{array}{l}\text { Universitas Cenderawasih } \\
\text { (UNCEN) }\end{array}$ & 45 \\
\hline 2 & $\begin{array}{l}\text { Universitas Yapis Papua } \\
\text { (UNIYAP) }\end{array}$ & 30 \\
\hline 3 & $\begin{array}{l}\text { Sekolah Tinggi Ilmu } \\
\text { Ekonomi Port Numbay } \\
\text { Jayapura }\end{array}$ & 30 \\
\hline 4 & $\begin{array}{l}\text { Universitas Sains dan } \\
\text { Teknologi Jayapura (USTJ) }\end{array}$ & 30 \\
\hline \multicolumn{2}{|l}{ Jumlah } & 135 \\
\hline
\end{tabular}

Tabel 4.2

Ikhtisar Distribusi dan Pengembalian Kuesioner

\begin{tabular}{|c|l|c|c|}
\hline No & \multicolumn{1}{|c|}{ Keterangan } & $\begin{array}{c}\text { Jumlah } \\
\text { Kuesioner }\end{array}$ & Persentase \\
\hline 1 & Distribusi Kuesioner & 135 & $100 \%$ \\
\hline 2 & $\begin{array}{l}\text { Kuesioner yang } \\
\text { Kembali }\end{array}$ & 79 & $58,5 \%$ \\
\hline 3 & $\begin{array}{l}\text { Kuesioner yang tidak } \\
\text { kembali }\end{array}$ & 53 & $39,2 \%$ \\
\hline 4 & Kuesioner yang rusak & 3 & $2 \%$ \\
\hline 5 & $\begin{array}{l}\text { Kuesioner yang dapat } \\
\text { diolah }\end{array}$ & 76 & $56,3 \%$ \\
\hline
\end{tabular}

$\mathrm{n}=$ sampel $=68$

Responden Rate $=(76 / 79) \times 100 \%=96,2 \%$

Sumber: Data Primer diolah, 2018

\subsubsection{Karakteristik Responden}

Karakteristik responden pada kuesioner yang disebar 
pada pergruan tinggi adalah para Civitas akademik. Civitas akademik dalam penelitian ini adalah Dekan, Dosen, Staf hingga mahasiswa pada perguruan tinggi pada Universitas Cenderawasih (UNCEN), Universitas Yapis Papua (UNIYAP), Universitas Sains dan Teknologi Jayapura (USTJ), dan Sekolah Tinggi Ilmu Ekonomi Port Numbay Jayapura. Adapun karakteristik responden sebagai berikut:

\section{Gambar 4.1}

Ditribusi Perguruan Tinggi Responden

Sumber: Data Primer diolah, 2018

Berdasarkan rincian diatas, maka besar kecilnya jumlah responden, dapat digambarkan dalam pie chart berikut ini:

Gambar 4.1

Ditribusi Perguruan Tinggi Responden

Dari gambar diatas dapat diketahui bahwa responden terbanyak pada pergruan tinggi di kota Jayapura yaitu Universitas Cenderawasih sebanyak 37\% atau berjumlah 28 responden, dan responden dari perguruan tinggi yang paling sedikit ada pada Universitas Sains dan Teknologi Jayapura.

\section{Gambar 4.2}

\section{Ditribusi Karakteristik Responden}

Berdasarkan grafik diatas, dapat diketahui bahwa responden berjenis kelamin perempuan lebih banyak, yaitu sebesar $55,3 \%$ atau sejumlah dengan 42 responden. Sedangkan responden laki-laki hanya sebesar 44,7\%. Responden dengan pendidikan atau lulusan Magister sebesar 52,6\% lebih banyak dari lulusan SLTA, Sarjana dan Doktor. Sedangkan responden berdasarkan usia yaitu usia 31-42 yang terbanyak yaitu $40,8 \%$.

\subsubsection{Karakteristik Responden AHP (Informan)}

Penelitian ini memiliki dua jenis responden yang berbeda yaitu responden untuk civitas akademik pada perguruan tinggi Kota Jayapura dan Responden yang ditujukan kepada anggota SPI dalam menentukan bobot Good University Governance. Kuesioner yang disebar kepada anggota SPI sebanyak 10 informan namun yang diterima kembali berjumlah 7 kuesioner.

Berikut rincian karakteristik informan:

\begin{tabular}{|l|l|}
\hline No & Jabatan \\
\hline 1 & $\begin{array}{l}\text { Ketua Satuan Pengawas Intern (SPI) Universitas } \\
\text { Tanjungpura }\end{array}$ \\
\hline 2 & $\begin{array}{l}\text { Ketua Satuan Pengawas Intern (SPI) Universitas } \\
\text { Bangka Belitung }\end{array}$ \\
\hline 3 & $\begin{array}{l}\text { Ketua Satuan Pengawas Intern (SPI) Universitas } \\
\text { Trunojoyo Madura }\end{array}$ \\
\hline 4 & $\begin{array}{l}\text { Anggota Satuan Pengawas Intern (SPI) } \\
\text { Politeknik Negeri Jakarta }\end{array}$ \\
\hline 5 & $\begin{array}{l}\text { Ketua Satuan Pengawas Intern (SPI) Politeknik } \\
\text { Negeri Bandung }\end{array}$ \\
\hline 6 & $\begin{array}{l}\text { Sekretaris Satuan Pengawas Intern (SPI) } \\
\text { Universitas Jember }\end{array}$ \\
\hline 7 & $\begin{array}{l}\text { Anggota Satuan Pengawas Intern (SPI) } \\
\text { Universitas Padjajaran }\end{array}$ \\
\hline 8 & $\begin{array}{l}\text { Sekretaris Satuan Pengawas Intern (SPI) } \\
\text { Universitas Cenderawasih }\end{array}$ \\
\hline 9 & $\begin{array}{l}\text { Anggota Satuan Pengawas Intern (SPI) } \\
\text { Universitas Cenderawasih }\end{array}$ \\
\hline 10 & $\begin{array}{l}\text { Anggota Satuan Pengawas Intern (SPI) } \\
\text { Universitas Cenderawasih }\end{array}$ \\
\hline 11 & $\begin{array}{l}\text { Anggota Satuan Pengawas Intern (SPI) } \\
\text { Universitas Cenderawasih }\end{array}$ \\
\hline Sum & \\
\hline
\end{tabular}

Sumber: Data Primer diolah, 2018

\subsection{Analisis Model Good University Governance}

Good University Governance dalam penelitian ini menggunakan prinsip GUG yang dikembangkan oleh Wijatno (2009) terdiri dari 5 indikator yaitu Transparansi, Akuntabilitas, Responsibilitas, Independensi dan Keadilan. Dengan masing-masing memiliki 3 subindikator. Model AHP dapat digambarkan sebagai berikut:

Tabel 4.5

Sub Indikator GUG

\begin{tabular}{|l|l|}
\hline T1 & $\begin{array}{l}\text { Sosialisasi tentang rencana strategis } \\
\text { yang telah dikembangkan kepada } \\
\text { civitas akademik }\end{array}$ \\
\hline T2 & $\begin{array}{l}\text { Keterbukaan dibidang keuangan, } \\
\text { sistem dan prosedur penerimaan } \\
\text { mahasiswa baru, sistem akuntansi, } \\
\text { sistem pelaporan, rekrutmen dosen }\end{array}$ \\
\hline
\end{tabular}




\begin{tabular}{|c|c|}
\hline & $\begin{array}{l}\text { dan karyawan serta pemilihan } \\
\text { pejabat structural }\end{array}$ \\
\hline T3 & $\begin{array}{l}\text { Kebijakan diperguruan } \\
\text { didokumentasikan } \\
\text { dikomunikasikan kepada pihak } \\
\text { dan } \\
\text { intern maupun ektern perguruan } \\
\text { tinggi. }\end{array}$ \\
\hline $\mathrm{A} 1$ & $\begin{array}{l}\text { Memiliki uraian, tugas dan } \\
\text { tanggung jawab yang jelas dari } \\
\text { setiap pejabat structural, anggota } \\
\text { senat fakultas/akademis, dosen dan } \\
\text { karyawan yang selaras dengan visi, } \\
\text { dan rencana strategis. }\end{array}$ \\
\hline A2 & $\begin{array}{llr}\text { Sistem } & \text { pengendalian } & \text { intern } \\
\text { dilakukan secara efektif } & \text { dalam } \\
\text { pengelolaan perguruan tinggi } & \end{array}$ \\
\hline A3 & $\begin{array}{l}\text { Pengukuran kinerja untuk tujuan } \\
\text { mengevaluasi dan mengendalikan } \\
\text { aktifitas organisasi dapat dicapai } \\
\text { dengan efisien dan efektif. }\end{array}$ \\
\hline $\mathrm{R} 1$ & $\begin{array}{l}\text { kepatuhan terhadap peraturan } \\
\text { perundang-undangan yang berlaku } \\
\text { tentang penyelenggaarn perguruan } \\
\text { tinggi }\end{array}$ \\
\hline $\mathrm{R} 2$ & $\begin{array}{l}\text { kepatuhan terhadap peraturan } \\
\text { perundang-undangan yang telah } \\
\text { dibuat }\end{array}$ \\
\hline R3 & $\begin{array}{lcr}\text { Pelaksanaan } & \text { tanggung } & \text { jawab } \\
\text { terhadap } & \text { masyarakat } & \text { dan } \\
\text { lingkungan } & \text { sehingga } & \text { dapat } \\
\text { terpelihara } & \text { kesinambungan } & \text { usaha } \\
\text { dalam jangka panjang. } & \\
\end{array}$ \\
\hline I1 & $\begin{array}{l}\text { Pengambilan keputusan perguruan } \\
\text { tinggi perlu terpisah dari pemerintah } \\
\text { yang memilikinya sehingga } \\
\text { terbebas dari benturan kepentingan } \\
\text { didalamnya }\end{array}$ \\
\hline I2 & $\begin{array}{l}\text { Menghindari terjadinya dominasi } \\
\text { oleh pihak manapun. }\end{array}$ \\
\hline I3 & $\begin{array}{l}\text { Pelaksanaan tugas dan fungsi dalam } \\
\text { perguruan tinggi bebas dari segala } \\
\text { pengaruh dan tekanan yang bersifat } \\
\text { intern dan ekstern. }\end{array}$ \\
\hline K1 & $\begin{array}{l}\text { perlakuan yang setara dan wajar } \\
\text { kepada pihak yang berkepentingan } \\
\text { sesuai dengan manfaat dan } \\
\text { kontribusi yang diberikan kepada } \\
\text { universitas }\end{array}$ \\
\hline $\mathrm{K} 2$ & $\begin{array}{llr}\text { Diberikan kesempatan yang sama } \\
\text { dalam penerimaan karyawan, } \\
\text { mahasiswa, } & \text { berkarir } & \text { dan } \\
\text { melaksanakan } & \text { tugasnya } & \text { secara } \\
\text { profesional } & \text { tanpa } & \text { adanya } \\
\text { diskriminasi } & & \\
\end{array}$ \\
\hline K3 & $\begin{array}{l}\text { Penerapan reward dan punishment } \\
\text { kesemua pihak tanpa adanya } \\
\text { diskriminasi. }\end{array}$ \\
\hline
\end{tabular}

Berdasarkan hasil penginputan data dari kuesioner
AHP yaitu pengisian tabel berpasangan, maka data tersebut diolah dengan menggunakan aplikasi Expert Choice untuk mendapatkan bobot prioritas dari indicator maupun sub indikator.

\section{Keterangan:}

1. Jika Indeks Inkonsistensi $<0.10$ dikatakan konsisten, sedangkan jika nilainya $0,10 \square$ IIc $\square$ 0,20 dikatakan cukup konsisten, dan > 0,20 tidak konsisten;

2. Eigen value adalah nilai bobot diberikan berdasarkan perbandingan kepentingan antar indikator/variabel.

Dari tabel 4.5 diatas dapat dilihat masing-masing bobot prioritas dari Indikator maunpun sub indikator yang ditentukan oleh informan Anggota SPI. Selain melihat bobot dari masing-masing indiktaor maupun sub indikator, perlu dilihat juga indeks konsistensinya.

Dengan model AHP yang memakai persepsi manusia sebagaiinputnya maka ketidakkonsistenan mungkin terjadi karena manusia memiliki keterbatasan dalam menyatakan persepsinya secara konsistenterutama kalau harus membandingkan banyak kriteria. Berdasarkankondisi ini maka manusia dapat menyatakan persepsinya tersebut akan konsisten nantinya atau tidak.

Pengukuran konsistensi ini dimaksudkan untuk melihat ketidakkonsistenan respon yang diberikan responden. Jika $\mathrm{CR}<0,1$ maka nilai perbandingan berpasangan pada matriks kriteria yang diberikan konsisten. Jika CR > 0,1 maka nilai perbandingan berpasangan pada matriks kriteria yang diberikan tidak konsisten. Sehingga jika tidak konsisten, maka pengisian nilai-nilai pada matriks berpasangan pada unsure kriteria maupun alternatif harus diulang.

Pada tabel 4.5 nilai indeks konsistensi dari masing-masing indikator yaitu untuk variabel transparansi sebesar 0,03. Variable akuntabilitas sebesar 0,06, variable Responsibilitas sebesar 0,08, variable Independensi sebesar 0,12 dan variabel keadilan sebesar 0,00. Selain itu untuk nilai konsistnsi secara keseluruhan sebesar 0,01. Dapat disimpulkan bahwa secara keseluruhan penilaian informan dinyatakan konsisten. 
Sedangkan untuk melihat bobot prioritas dari masing-masing sub variabel dan variabel dilihat dari nilai eigen valuenya. Ditemukan hasil bahwa variabel independensi memiliki nilai tertinggi sebesar 0,227. Prioritas kedua ada pada variabel transaparansi sebesar 0,209 selanjutnya diikuti oleh variabel akuntabilitas sebesar 0,206. Variabel keadilan 0,201 dan terakhir adalah variabel responsibilitas sebesar 0,157.

Dari bobot prioritas diatas, telah dihasilkan variabel yang sangat diutamakan dalam pengelolan perguruan tinggi adalah variabel independensi. Perguruan tinggi memiliki wewenangnya sendiri untuk mngatur segala aktifitas didalamnya, yang dikenal dengan otonomi perguruan tinggi. Pengembangan pendidikan dan pengajaran di perguruan tinggi berpedoman pada "Tri Dharma Perguruan Tinggi”, yaitu Pendidikan, Penelitian, dan Pengabdian Masyarakat. Untuk itu perguruan tinggi perlu mengembangkan kebebasan akademik, kebebasan mimbar akademik, dan otonomi ilmu pengetahuan (UU No.2 tahun 2003 tentang Sistem Pendidikan Nasional). Proses menuju otonomi perguruan tinggi antara lain berkaitan dengan pengembangan budaya profesionalisme dengan ciri-ciri memilki keahlian (expertise), tanggung jawab (responsibility), dan kesejawatan (corporateness).

Mengacu pada Deklarasi Lima tentang "Academic Freedom and Autonomy of Higher Education", dapat dikemukakan di sini beberapa butir prinsip dan substansi salah satunya menyebutkan bahwa Otonomi perguruan tinggi mengandung pengertian bahwa lembaga perguruan tinggi harus memiliki independensi atau kebebasan dalam mengambil keputusan dan merumuskan kebijakan yang menyangkut pengelolaan administrasi, keuangan, pendidikan, penelitian, pengabdian masyarakat, kerja sama dan aktivitas lain yang berkaitan, tanpa campur tangan (intervensi) pemerintah atau kekuatan lain. Serta seluruh anggota masyarakat akademik memiliki hak untuk menjalankan tugasnya tanpa diskriminasi dan tanpa rasa takut akan adanya gangguan, larangan, atau represi dari mana pun (Laksiri, 1989).

Dengan mengalikan eigen value setiap indikator dengan eigen value variabel maka diperoleh model GUG sebagai berikut:
Tabel 4.6

\section{Model GUG PTN Se Kota Jayapura}

Berdasarkan tabel diatas terdapat nilai koefisien dari masing-masing sub variabel. Dapat dilihat bahwa nilai koefisien tertinggi pada variabel transparansi terletak pada sub variabel kedua (T2) sebesar 0,105 yaitu Keterbukaan dibidang keuangan, sistem dan prosedur penerimaan mahasiswa baru, sistem akuntansi, sistem pelaporan, rekrutmen dosen dan karyawan serta pemilihan pejabat structural. Hal ini dikarenakan bahwa dalam pengelolaan perguruan tinggi keterbukaan merupakan kunci utama tercapainya tujuan pengelolaan yang baik, terutama dalam bidang keuangan. Pelaksanaan fungsi manajemen keuangan dimaksudkan agar dalam pengelolaan keuangan dapat memenuhi prinsip-prinsip transparansi. Dalam pengelolaan PNBP fungsi manajemen meliputi perencanaan dan penyusunan anggaran, pelaksanaan anggaran, pelaporan dan pengawasan. Selain itu jumlah penerimaan mahasiswa baru juga untuk mengetahui besaran PNBP yang dihasilkan oleh suatu perguruan tinggi. Selain bidang keuangan, unsure penunjang selanjutnya yaitu pada bidang sumber daya manusia. Perekrutan dosen serta pegawai harus dilakukan secara terbuka dan tidak mengandung unsur nepotisme. Sehingga profesionalisme dan kualitas SDM dapat tercapai.

Nilai koefisien tertinggi pada variabel akuntabilitas terletak pada sub variabel kedua (A2) yaitu Sistem pengendalian intern dilakukan secara efektif dalam pengelolaan perguruan tinggi. Hal ini dikarenakan bahwa Keberadaan sistem pengendalian internal sangat penting bagi suatu insti-tusi karena Pengendalian yang lemah akan mengakibatkan kerugian, skandal, kegagalan, bahkan kebangkrutan (bankrupcy) atau rusaknya reputasi Jika risiko dibiarkan saja tanpa adanya media pengendali risiko, maka hal tersebut akan menjadi permasalahan institusi dalam mencapai tujuannya.

Oleh karena itu perguruan tinggi memiliki unit kerja yang bertugas mengawasi pengelolan perguruan tinggi itu sendiri yang disebut dengan unit Satuan Pengawasa 
Internal. Menurut Peraturan Menteri Nomor 47 Tahun 2011dalam Pasal 1 poin (b) SPI adalah satuan pengawasan yang dibentuk untuk membantu terselenggaranya pengawasan terhadap pelaksanaan tugas unit kerja di lingkungan Kementerian Pendidikan Nasional.

SPI mempunyai wewenang PENUH, BEBAS, dan TIDAK TERBATAS untuk melakukan akses terhadap semua bentuk dokumen, personalia dari aparat atau penyelenggara perguruan tinggi maupun objek penyelenggaraan perguruan tinggi, dan fasilitas fisik milik perguruan tinggiguna mendapatkan data dan informasi yang diperlukan dan berkaitan dengan pelaksanaan tugas auditnya.(Wiwoho, 2017)

Nilai koefisien tertinggi pada variabel responsibiltas ada pada sub variabel R1 sebesar 0,0978 yaitu pada kepatuhan terhadap peraturan perundang-undangan yang berlaku tentang penyelenggaarn perguruan tinggi. Hal ini dikarenakan bahwa pengelolaan perguruan tinggi harus berdasarkan peraturan dan regulasi yang berlaku, yaitu pada Undang-undang No 12 Tahun 2012 tentang pendidikan tinggi. Agar tata kelola perguruan tinggi dapat dijalankan dengan baik, maka organisasi dan mekanisme pengelolaan perguruan tinggi tersebut perlu diatur dalam peraturan yang disebut statute perguruan tinggi. Statuta perguruan tinggi adalah peraturan dasar Pengelolaan Perguruan Tinggi yang digunakan sebagai landasan penyusunan peraturan dan prosedur operasional di Perguruan Tinggi. (Pasal 1 angka 16 PP No 4 Tahun 2014).

Nilai koefisien tertinggi pada variabel Independensi yaitu pada sub variabel pertama (I1) sebesar 0,088 yaitu Pengambilan keputusan perguruan tinggi perlu terpisah dari pemerintah yang memilikinya sehingga terbebas dari benturan kepentingan didalamnya. Hal ini dikarenakan bahwa perguruan tinggi memiliki otonomi yang mengurus pengelolan sendiri tanpa adanya campur tangan pemerintah dalam menentukan kebijakan dan pengambilan keputusan yang tidak sesuai dengan tri darma peguruan tinggi.

Nilai koefisien tertinggi pada variabel Keadilan terletak pada sub variabel ketiga (K3) sebesar 0,0744 yaitu pada Penerapan reward dan punishment kesemua pihak tanpa adanya diskriminasi. Sebab reward akan memberikan motivasi lebih bagi suatu individu untuk melakukan pekerjaanya dengan maksimal serta punishment memberikan efek jera bagi individu yang menyimpang dari tujuan perguruan tinggi.

Berdasarkan hasil perhitungan bobot prioritas dengan Model AHP tentang penerapan GUG pada Perguruan tinggi di Kota Jayapura, maka nilai dari masing-masing variabel dan sub variabel dapat digambarkan pada bagan dibawah ini:

Dari tabel di atas dapat diturunkan model GUG yang aplikatif dalam bentuk Indeks Komposit sebagai berikut:

$\mathrm{GUG}=0.0571 \mathrm{~T} 1+0.1055 \mathrm{~T} 2+0.0464 \mathrm{~T} 3+0.0484 \mathrm{~A} 1$ $+0.1055 \mathrm{~A} 2+0.0521 \mathrm{~A} 3+0.0978 \mathrm{R} 1+0.0367 \mathrm{R} 2+$ $0.0225 \mathrm{R} 3+0.0883 \mathrm{I} 1+0.0536 \mathrm{I} 2+0.0851 \mathrm{I} 3+$ $0.0559 \mathrm{~K} 1+0.0708 \mathrm{~K} 2+0.0744 \mathrm{~K} 3$

Model GUG ini selanjutnya digunakan untuk menilai penerapan GUG di PTN Se Kota Jayapura, dengan cara menyebar kuesioner kepada sampel yang telah ditetapkan sebelumnya. Dimana kuesioner tersebut disusun dalam bentuk Skala Likert dengan bilangan ordinal antara 1 (sangat tidak setuju) sampai dengan 5 (sangat setuju).

Selanjutnya, sebelum hasil jawaban responden tersebut di masukan dalam model GUG, terlebih dahulu dihitung Indeks Tunggal, yang dimaksudkan untuk memberi standarisasi agar karakteristik indikator dapat disamakan secara keseluruhan. Rumus Indeks Tunggal yang digunakan sebagai berikut:

Dimana berdasarkan Skala Likert yang digunakan diketahui bahwa nilai Maximum $=5$, nilai minimum $=$ 1.

Keterangan:

Dengan menggunakan metode five box (lima kelas) bisa diperoleh nilai interval dengan cara: (Max - Min) / 5. Misalkan, a $(20.90-0) / 5=4.18$

Selengkapnya hasil penetapan kriteria untuk masing-msing variabel GUG, dan penerapan GUG sebagai berikut:

\subsection{Penerapan Good University Governance Pada}




\section{Perguruan Tinggi di Kota Jayapura.}

Dari model Good University Governance yang sudah dihasilkan dari model GUG AHP kemudian didapat indeks komposit dari masing-masing responden kemudian dijumlahkan dan dicari nilai rata-rata dari masing-masing sub variabel, maka akan dihasilkan skor dari masing-masing variabel. Skor tersebut selanjutnya dibandingkan dengan tabel kriteria dari masing-masing variabel. Kriteria tersebut terdiri dari jenis kriteria Sangat Tinggi, Tinggi, Sedang, Rendah dan Sangat Rendah. Berikut tabel penerapan Good University Governance pada Perguruan Tinggi di Kota Jayapura.

Pada tabel 4.10 merupakan hasil penerapan Good University Goverance di Kota Jayapura dengan menunjukkan skor sebesar 79,19. Skor tersebut berada pada range 60,01 - 80,00 yaitu masuk kedalam kriteria penerapan yang "tinggi". Nilai sub variabel dan variabel diatas merupakan nilai rata-rata indeks komposit yang dijumlah kemudian akan didapat skor masing-masing variabel dan dapat ditentukan kriterianya dengan melihat tabel 4.9 yaitu tabel Interval Nilai Kriteria Variabel-Variabel GUG.

Skor pada variabel transparansi sebesar 16,41 berada pada interval 12,55 - 16,72 yaitu masuk dalam kriteria "tinggi" . Skor pada variabel Akuntabilitas sebesar 15,62 berada pada interval 12,37 - 16,48 yaitu masuk dalam kriteria "tinggi". Skor pada variabel Responsibilitas sebesar 12,43 berada pada interval 9,43 - 12,56 yaitu masuk dalam kriteria “tinggi”. Skor pada variabel Independensi sebesar 18,16 berada pada interval 13,63- 18,1 yaitu masuk dalam kriteria "tinggi". Skor pada variabel Keadilan sebesar 16,57 berada pada interval 16,09 - 20,10 yaitu masuk dalam kriteria "sangat tinggi".

Dari kelima variabel tersebut empat variabel mendapatkan kriteria yang sama yaitu, Transparansi, Akuntabilitas, Responsibiltas dan Independensi mendapat kriteria "Tinggi". Sedangkan Keadilan memiliki kriteri "sangat tinggi".

Secara keseluruhan penerapan Good University Governance di Perguruan Tinggi Kota Jayapura sudah berada pada pengelolaan yang baik, namun ada beberapa hal yang menjadi pokok utama dan poin penting jika dilihat pada skor masing-masing sub variabel. Pada Variabel transparansi nilai tertinggi ada pada nilai sub variabel kedua dengan nilai $\mathrm{T} 2$ sebesar 8,19 . Seluruh perguruan tinggi telah sepakat bahwa Keterbukaan dibidang keuangan, sistem dan prosedur penerimaan mahasiswa baru, sistem akuntansi, sistem pelaporan, rekrutmen dosen dan karyawan serta pemilihan pejabat structural harus dilaksanakan demi tercapainya pengelolaan yang baik. keterbukaan di bidang keuangan mencakup tahap perencanaan, yaitu pada saat penyusunan Rencana Kerja Anggaran Kementerian/Lembaga (RKA-KL) melibatkan semua unit kerja untuk saling membahas Usulan Lembar Kegiatan (ULK), Kerangka Acuan Kerja (TOR) hingga Rincian Anggaran Belanja.

Asas keterbukaan informasi adalah satu kewajiban yang harus dilakukan oleh lembaga pendidikan tinggi. Hal ini telah di amanatkan dalam Undang-Undang No 14 Tahun 2008 tentang Keterbukaan Informasi Publik (KIP), yang menekankan perguruan tinggi negeri untuk selalu memberikan pelayanan informasi yang terbuka, transparan dan bertanggung jawab kepada masyarakat. Artinya perguruan tinggi wajib membuka dan menyediakan informasi mengenai anggaran, kebijakan dan program di media cetak maupun media online sesuai peraturan perundang-undangan.

Pada Variabel Akuntabilitas nilai tertinggi ada pada nilai sub variabel kedua dengan nilai A2 sebesar 7,91, yaitu terkait dengan adanya Sistem Pengendalian Intern dilakukan secara efektif dan efisien dalam pengelolaan perguruan tinggi. Sistem pengendalian intern memegang peranan kunci dalam mewujudkan akuntabilitas keuangan. Kelemahan sistem keuangan pada instansi pemerintah selama ini terjadi karena lemahnya desain dan pelaksanaan sistem pengendalian intern.

Sistem Pengendalian Internal tidak lepas dari peran Satuan Pengawasan Intern (SPI) Perguruan Tinggi. Internal auditor atau SPI dianggap penting dalam mewujudkan penciptaan Perguruan Tinggi yang mampu melaksanakan perannya serta mampu mencegah terjadinya kecurangan (fraud) yang terjadi di manajemen Perguruan Tinggi. Auditor internal 
dipandang memiliki peran penting dalam upaya mewujudkan penciptaan Perguruan Tinggi yang mampu memiliki pengelolaan yang baik (Good University Governance).(Untari, 2015)

Pada Variabel Responsibilitas nilai tertinggi ada pada nilai sub variabel pertama dengan nilai R1 sebesar 7,79. yaitu terkait dengan Kepatuhan Terhadap Peraturan Perundang-undangan yang berlaku tentang penyelenggaran perguruan tinggi. Peraturan dalam pengelolaan perguruan tinggi dituangkan dalam Undang-undang Nomor 12 Tahun 2012.

Variabel Independensi memiliki nilai sub variabel tertinggi pada I3 sebesar 6,94 yaitu pada Pelaksanaan tugas dan fungsi dalam perguruan tinggi bebas dari segala pengaruh dan tekanan yang bersifat intern dan ekstern. Perguruan tinggi mempunyai otonomo sendiri untuk mengatur pengelolaanya, tanpa unsure campur tangan pemerintah. Namun tidak dapat dipungkiri bahwa perguruan tinggi juga tidak lepas dari nuansa politik.

Dari keempat variabel diatas, variabel keadilan lah yang masuk dalam kategori sangat baik, dengan sub variabel tertinggi ada pada K2 sebesar 6,10 yaitu Diberikan kesempatan yang sama dalam penerimaan karyawan, mahasiswa, berkarir dan melaksanakan tugasnya secara profesional tanpa adanya diskriminasi. Sebab keadilan dapat mempengaruhi motivasi setiap individu.

\section{Kesimpulan, Keterbatasan Penelitian dan Saran Kesimpulan}

Penelitian ini dilakukan pada beberapa Perguruan Tinggi di Kota Jayapura untuk mengetahui seberapa besar penerapan Good University Governance pada beberapa Perguruan Tinggi di Kota Jayapura. Berdasarkan tujuan penelitian dan hasil penelitian maka dapat disimpulkan beberapa hal sebagai berikut: a. Berdasarkan penilaian dari Tim SPI untuk menentukan bobot Indikator GUG, ditemukan hasil bahwa Transaparansi mempunyai bobot sebesar 0,209. Kedua adalah akuntabilitas dengan nilai sebesar 0,206. Ketiga adalah Keadilan sebesar 0,157. Keempat adalah Independensi sebesar 0,227 , serta yang terakhir adalah Responsibilitas sebesar 0,201. Masing-masing sub variabel juga memiliki bobot nilai berbeda-beda. Sehingga dari bobot tersebut didapatlah model GUG yang nilai masing-masing bobot sub variabel dikalikan dengan nilai indeks tunggal responden, yang kemudian akan dihasilan indeks komposit dari masing-masing responden.

b. Penerapan Good University Governance di kota Jayapura menghasilkan nilai sebesar 79,19 masuk pada kriteria tinggi. Dalam arti penerapan GUG sudah dirasakan oleh beberapa perguruan tinggi di kota jayapura, namun masih dalam tahap pembenahan agar hasilnya dapat berjalan dengan optimal.

\section{Keterbatasan}

Berdasarkan kesimpulan di atas, maka keterbatasan penelitian ini adalah sebagai berikut:

a. Resposnden dalam penelitian ini belum sampai pada jumlah yang diharapkan peneliti, yang disebakan karena keterbatasan waktu.

b. Perguruan tinggi pada penelitian ini bervariasi, sehingga penelitian ini belum dilakukan pada perguruan tinggi yang homogen.

c. Sampel penelitian ini hanya pada empat perguruan tinggi di Kota Jayapura, sehingga hasilnya belum bisa digeneralisasi.

\section{Saran}

Berdasarkan keterbatasan diatas, maka saran dalam penelitian ini adalah sebagai berikut:

a. Bagi Perguruan Tinggi: Penerapan prinsip Good University Governance harus lebih ditingkatkan, demi tercapainya tujuan perguruan tinggi. Beberapa hal yang menjadi perhatian utama yaitu terkait:

Transparansi di perguruan tinggi sangat penting dengan melakukan sosialisasi kepada civitas akademik terkait pengelolaan serta memberikan informasi kepada public melalui website perguruan tinggi.

- Akuntabilitas menjadi evaluasi dari kinerja perguruan tinggi salah satunya dengan meningkatkan sistem pengendalian internal agar meminimalisasi serta mengawasai bentuk penyimpangan-penyimapan pada perguruan tinggi. Dengan

- Peraturan pengelolaan perguruan tinggi sudah tercantum dalam Undang-undang Nomor 12 Tahun 
2012, oleh sebab itu respon dari seluruh civitas akaemik harus mematuhi peraturan yang berlaku.

- Pemberian reward dan punishment sangat penting dalam memberikan motivasi bagi civitas akaemik, untuk itu pemberian reward dan sanksi yang tepat sasaran sangat diperlukan.

b. Bagi Peneliti Selanjutnya, penentuan sampel perguruan tinggi lebih dipeluas lagi, dengan menggunakan perguruan tinggi yang ada di Provinsi Papua.

\section{Daftar Pustaka}

Andrianto, N. (2007). Good e-Government: Transparansi dan Akuntabilitas Publik Melalui e-Government. Malang: Banyumedia Publising.

Anggriwan, F. ., \& Nurcholis. (2014). Good Corporate Governance in the Public Service Agency (Case Study at University of Brawijaya Malang). Jurnal Ilmiah Mahasiswa FEB, Vol 2, No 2, Semester Genap 2013/2014.

Baihaki. (2016). Persepi Mahasiswa Terhadap Tata Kelola Universitas Lampung (Good University Governance). Skripsi.

Budiardjo, M. (1998). Menggapai kedaulatan Untuk Rakyat. Bandung: Mizan.

Christensen, T. (2011). University governance reforms : potential problems of more autonomy?, (123), 503-517.

https://doi.org/10.1007/s10734-010-9401-z

Djanali, S. (2005). Tata Kelola. Jakarta: Dikjen Dikti Depdiknas.

Eli, S. (2013). Good University Governance: Prinsip dan Implementasi Dalam Penggalian Pendapatan. Malang: Gunung Samudra.

Esha, M. I. (2011). Pemikiran Mwujudkan Good University Governance di Perguruan Tinggi Islam. El-Hikmah Fakultas Tarbiyah UIN, (50), 91-101.

Ganga, F., Quiroz, J., \& Fossatti, P. (2017). A synchronic analysis of university governance : a theoretical view of the sixties and seventies I. Educ. Pesqui., São Paulo, v. 43, N. 2, P. 553-568,
Abr.jun., 2017, 553-568.

Indrajit, R. E., \& Djokopranoto. (2006). Manajemen Perguruan Tinggi Modern. Jakarta: CV Andi Offset.

Jogiyanto, H. . (2004). Metodologi Penelitian Bisnis: Salah Kaprah Dan Pengalaman-Pengalaman. Yogyakarta: BPFE.

Jubaedah, E., Nugraha, L., \& Faozan, H. (2008). Model Pengukuran Pelaksanaan Good Governance di Pemerintah Daerah Kabupaten/kota. Bandung: PKP2AI LAN,.

Krina, L. L. (2003). Indikator \& Alat Ukur Prinsip Akuntabilitas, Transparansi \& Partisipasi. Sekretariat Good Public Governance BPPN, 299-381.

Laksiri, F. (1989). The Lima Declaration on Academic Freedom and Autonomy of Institutions of Higher Education. Higher Education Policy, Volume 2(Issue 1), 49-51.

Muktiyanto, A. (2016). Good University Governance dan Kinerja Program Studi: Pengaruh Penerapan Akuntansi Manajemen, Teknik Manajemen, dan Pilihan Prioritas Strategi Sebagai Model Mediasi Fit. Disertasi.

Muslimah, S. (2016). Responsibilitas pelayanan publik pada rsud salewangan kabupaten Maros.

Peters, B. G. (2000). The Politics of Bureaucracy. London: Routledge.

Raharjo, E. (2007). Teori Agensi dan Teori Stewrship dalam Perspektif Akuntansi. Fokus Ekonomi, 2(1), 37-46.

Rosyid, A. (2014). Survei Atas Implementasi Good University Governance (Studi Kasus STAIN Pekalongan). Jurnal Penelitian, 11,No, $1 \mathrm{M}$, $172-188$

Shafratunnisa, F. (2015). Penerapan Prinsip Transparansi dan Akuntabilitas dalam Pengelolaan Keuangan kepada Stakeholders di SD Islam Binakheir.

Surayani, I. (2015). Good University Governance. Jurnal Riset Akuntansi, VII(2).

Trakman, L., \& South, N. (2008). Governance, 62(April), 63-83.

UGSC. (2012). The University Governance Screening 
Card A Tool for Benchmarking University

Governance. The Word Bank, 1-2.

Untari. (2015). Pengaruh Peran Satuan Pengawasan Intern (SPI) dan Penerapan.

Wening, S. (2007). Akreditasi Sebagai Strategi Pengembangan Program Studi Secara

Berkesinambungan. Paper Seminar Sistem Informasi Manajemen, 1307-1312.

Wijatno, S. (2009). Pengelolaan Perguruan Tinggi Secara Efisien, Efektif dan Ekonomis. Jakarta: Salemba Empat.

Wiwoho, J. (2017). Peran SPI Dalam Meningkatkan Pengelolaan Perguruan Tinggi. Forum SPI Nasional III PTN, Jayapura 19-21 April.

Yuwono, C. (2011). Pengaruh Peranan Auditor Internal Terhadap Penerapan Good Corporate Governance Pada BUMN Jember. SKRIPSI Universitas Diponegoro.

Zarkasyi, M. W. (2008). Good Corporate Governance (Pada Badan Usaha Manufaktur, Perbankan, dan Jasa Keuangan Lainya. Bandung: Alfhabeta. 